\title{
NEW RADIOCARBON DATES FOR THE EARLY NEOLITHIC OF THE WESTERN MEDITERRANEAN
}

\author{
Samuel van Willigen ${ }^{1} \cdot$ Irka Hajdas $^{2} \cdot$ Georges Bonani $^{2}$ \\ ABSTRACT. Understanding of processes that determined the expansion of farming and animal husbandry in south-western \\ Europe is hampered by poor chronologies of the early Neolithic in this region. This paper presents new radiocarbon dates, \\ which are used to construct such a chronological frame for a regional group of the most important culture of the early \\ Neolithic in the western Mediterranean: the Cardial culture.
}

\section{INTRODUCTION}

\section{Cardial Culture and Early Neolithic in Southwestern Europe}

The beginnings of Neolithic lifeways in the western Mediterranean region date back to $5700 \mathrm{cal} \mathrm{BC}$. It is believed that this development is a consequence of an expansion of early Neolithic groups from northern Italy to southern France (Guilaine et al. 2007). Existence of these scarcely documented Impressa groups is dated between 5700 and $5600 \mathrm{cal} \mathrm{BC}$. Sometime later, $5400 \mathrm{cal} \mathrm{BC}$, a new archaeological culture appeared: the Cardial culture, which is thus far the best-documented early Neolithic culture in the western Mediterranean region. The Cardial culture had a well-developed production economy that included foraging (cattle, sheep/goat, and pig) and farming (mainly emmer and einkorn wheat). There is much evidence for the existence of open-air settlements, even if cave sites remain the most important source of information. The impressed decoration executed before firing the vessels obtained with the edge of a cardium shell and the applied cordons are the most characteristic elements of this culture, which is attested from the southern Alps to Portugal and Morocco (van Willigen 2006). At about the same time, Neolithic lifeways spread to the hinterland. This continental Neolithization is mainly related to cultures other than the Cardial culture (i.e. the so-called "Epicardial" and "Neolitico interior"; van Willigen 2006; Bernabeu et al., in press).

\section{The Cardial Culture: Regional Groups}

Despite the common assumption, the Cardial culture was not evenly distributed along the western Mediterranean coast. The extension of this culture was connected to zones with soils rich enough to allow agricultural activity (loess basins and alluvial plains). The main favorable regions were the great coastal plains but also regions such as Granada, the Auvergne, and the Saône Valley, which are distant from the coast (Figure 1). The cultural materials of those groups show common features such as small round-bottomed bowls decorated with complex cardium patterns, big pots decorated with applicated cordons, and stone bracelets, but also some differences. These variations in the material culture allow definition of regional groups of the Cardial culture, like the Valencian group, the Catalanian group, and the Bas-Rhône-Provence group. Considering that it is reasonable to assume that the evolution of each group might be different, the chronological reconstructions should be performed on a regional level. Below, we focus on the Bas-Rhône-Provence group, which is located in the lower Rhône Valley and the Provence.

\footnotetext{
${ }^{1}$ MMSH-UMR 6636 (Aix-en-Provence, F) and Swiss National Museum, Zurich, Switzerland. Corresponding author. Email: Samuel.vanWilligen@slm.admin.ch.

${ }^{2}$ Ion Beam Physics ETH, Zurich, Switzerland.
}

C 2009 by the Arizona Board of Regents on behalf of the University of Arizona Proceedings of the 5th International ${ }^{14} \mathrm{C}$ and Archaeology Symposium, edited by Irka Hajdas et al. RADIOCARBON, Vol 51, Nr 2, 2009, p 831-838 


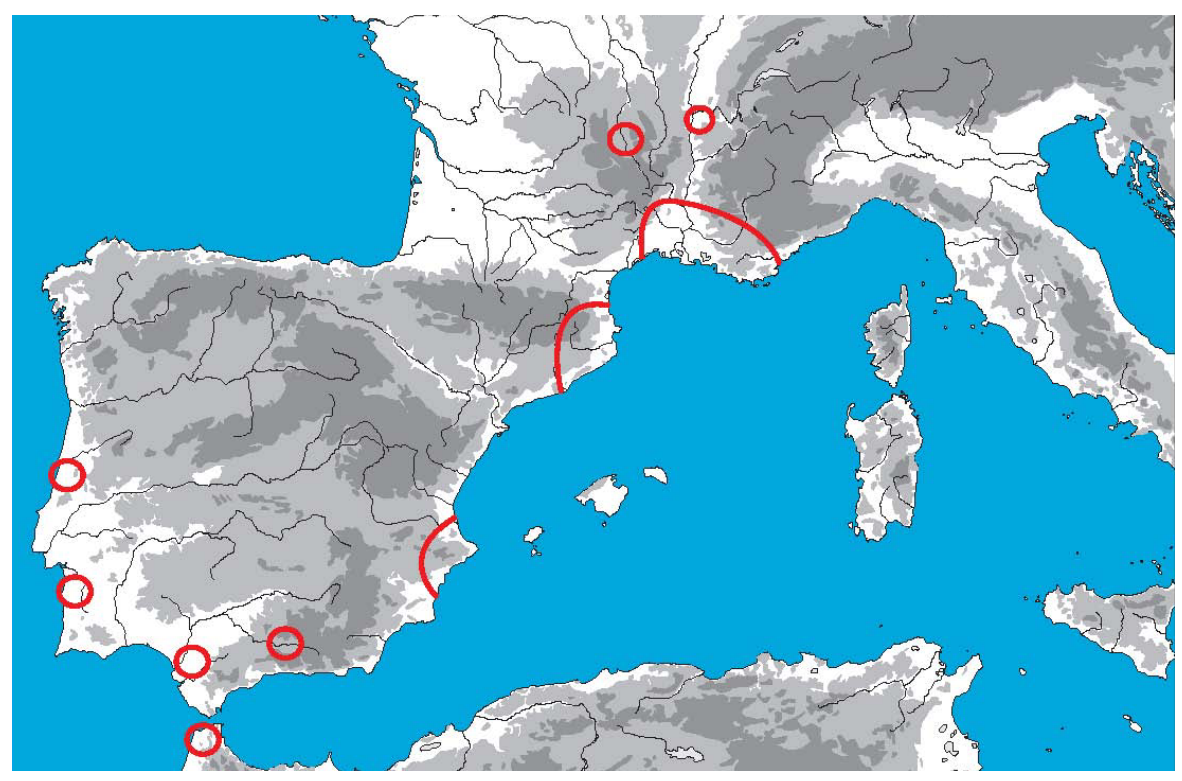

Figure 1 Map showing extension of the Cardial culture in southwestern Europe

\section{METHODS}

\section{Cardial Culture: Classification Using Ceramic Typology and Seriation}

Thanks to about 70 archaeological sites, the Bas-Rhône-Provence group is the best-defined regional group of the Cardial culture. However, one must keep in mind that only a small fraction of those sites were excavated and documented using modern techniques and methods. Moreover, most of the sites were located in caves, which were probably only occasionally visited for a specific purpose. Closed contexts like pits or graves are rare in this region and only 1 of the selected archaeological ensembles could be considered as a closed find: Céron, pit 1 . Thus, we have to deal mostly with occupation levels in caves and rockshelters with a variable time span ranging from a few months to a few hundred years. In such conditions, mixing between older and younger occupation levels is possible. In order to reduce this possibility, we chose to study occupation layers in caves/rockshelters or open-air sites, which are the result of observation during modern excavations. In this regard, we do not deal with closed finds but with ensembles, which can be considered as homogenous.

Our approach consisted of submitting the 15 ensembles that can be attributed to the Franco-Iberian Cardial in eastern Languedoc and western Provence (Table 1), to an automatic seriation of ceramic types defined on the basis of pottery characteristics using the statistic program WINBASP 5.2.

Despite the expected low precision of the chronology, the seriation showed a clear picture and allowed separation of the studied ensembles (mainly occupation levels in caves) into 2 groups (Figure 2). The first group (A) includes the sites of Grotte de l'Aigle (layer 5), Abri de la Font des Pigeons (layer 4/1949 and 17/1979), Baume d'Oullins (layer 6), and Les Petites Bâties. This group is characterized by finger-pressed cordons and bands of parallel cardium impressions. The second group (B) includes finds from Le Baratin, Aven de Rochas (layer 4.3inf), Abri 2 du Fraischamps (layers 4 and 3), Baume Saint-Michel (layer 5b), Escanin ("couche cardiale"), Baume Fontbrégoua (layers 47-45 and 44-35), Abri de l'Eglise (layer 11), and Grotte Lombard (layer 5). This group is characterized by orthogonal-sorted cordons and lentil-like applications as well as complex cardium patterns (bands of zig-zag lines). 
Table 1 List of the ensembles submitted to the seriation and references.

\begin{tabular}{ll}
\hline Site & Bibliography \\
\hline Abri de la Font des Pigeons, layer 4 (1949) & $\begin{array}{l}\text { Escalon de Fonton 1974; Courtin 1974; } \\
\text { Courtin et al. 1985 }\end{array}$ \\
Abri de la Font des Pigeons, layer 17 (1979) & $\begin{array}{l}\text { Escalon de Fonton 1974; Courtin 1974; } \\
\text { Courtin et al. 1985 }\end{array}$ \\
Baume Fontbrégoua, layers 47-45 & Courtin 1974; Courtin and Binder 1986 \\
Baume Fontbrégoua, layers 44-35 & Courtin 1974; Courtin and Binder 1986 \\
Baume d'Oullins, layer 6 & Roudil and van Willigen 2002 \\
Les Petites Bâties & Binder et al. 2002 \\
Aven de Rochas, layer 4.3inf & Beeching 1987 \\
Grotte de l'Aigle, layer 5 & Roudil et al. 1979 \\
Grotte Lombard, layer 5 & Binder 1991 \\
Baume Saint-Michel, layer 5b & Hameau et al. 1994 \\
Abri de l'Eglise, layer 11 & Courtin 1967 \\
Abri n ${ }^{\circ}$ du Fraischamps, layer 3 & Paccard 1957 \\
Abri n ${ }^{\circ}$ du Fraischamps, layer 4 & Paccard 1957 \\
Le Baratin & Courtin 1974 \\
Escanin-Eboulis, “couche cardiale” & Montjardin 1966, 1969-1970 \\
Abri de la Font des Pigeons, layer 11 (1974) & Courtin et al. 1985 \\
Station du Moulin, layer 6 & Beeching 1999 \\
Grotte du Mourre de la Barque, layer D4/16 & van Willigen 2003 \\
Céron, pit 1 & Buisson-Catil 2001 \\
\hline
\end{tabular}
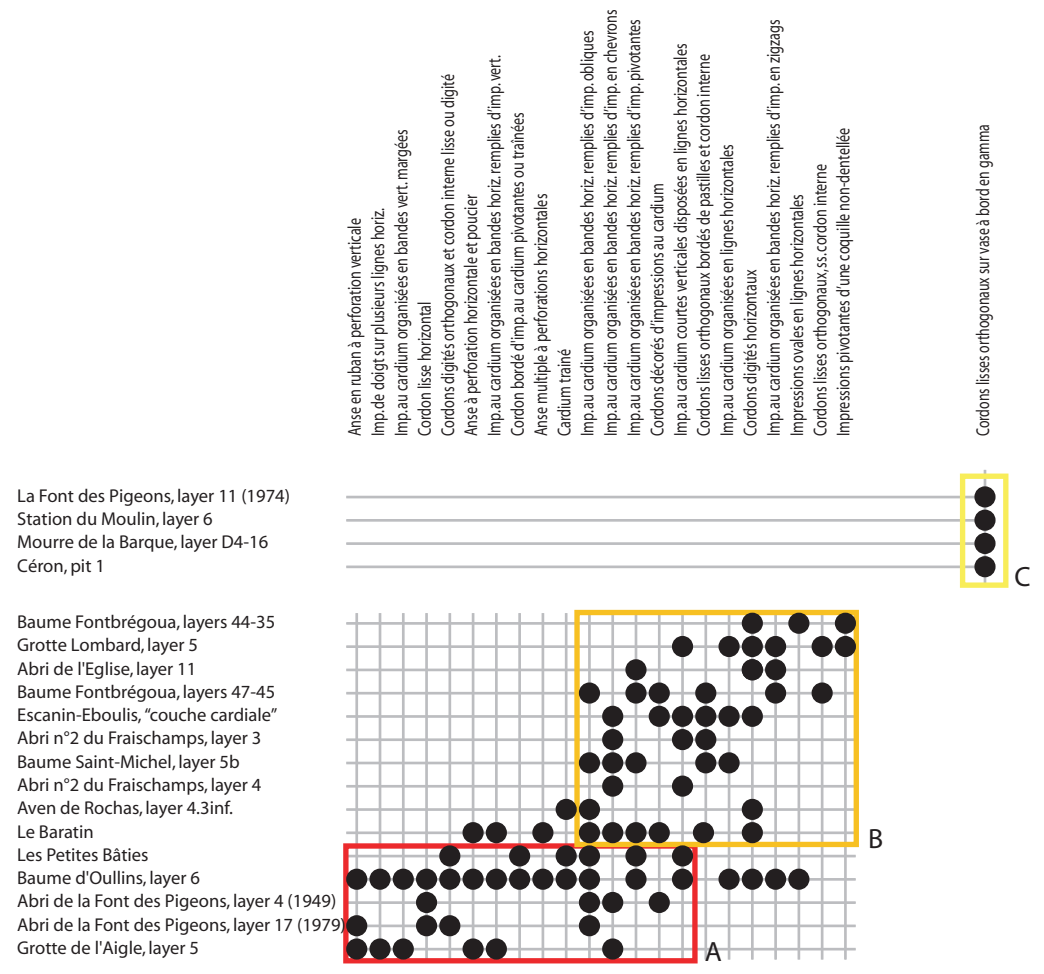

Figure 2 Automatic seriation of ceramic types for the Bas-Rhône-Provence group of the Cardial culture (group $\mathrm{C}$ was not submitted to the seriation process). 
A third group (C), consisting of 4 ensembles, was unfortunately underrepresented and thus not submitted to seriation: Céron (pit 1), Grotte du Mourre de la Barque (layer D4/16), Station du Moulin (layer 6), and Abri de la Font des Pigeons (layer 11/1974). Only 2 sites (Grotte du Mourre de la Barque and Station du Moulin) provide some information about the material culture. Besides the fact that the majority of the ceramic is undecorated and the cardium patterns are not present, the most characteristic element of this group is a large pot with orthogonal-sorted cordons and a socalled $\Gamma$-shaped rim. Nevertheless, because all the groups are present in the same region it is unlikely that they represent regional characteristics of the same phase.

\section{RESULTS AND DISCUSSION}

\section{Toward a Relative Chronology of Cardial Culture in Southeastern France}

We follow the hypothesis that these 3 groups represent 3 subsequent periods. Unfortunately, no stratigraphic sequence exists in this area, which could confirm that the groups $\mathrm{A}, \mathrm{B}$, and $\mathrm{C}$ follow each other. Only the stratigraphy of Abri de la Font des Pigeons yields elements of group A in the lowest layers (17-15 of the 1979 excavation). From the upper layers (14-11) comes a fragment of a large vessel with cordons and T-shaped rim (Dangel 1997); this indicates that group C is later than group A. Group B's position in the relative chronology, however, has to remain open. We can only propose that groups A and B share a couple of features (Figure 2), indicating their temporal proximity. Thus, stratigraphical evidence and typological reasons lead to the hypothetical sequence group A-B-C (Figure 3).

In order to improve this chronological relation between the groups $\mathrm{A}, \mathrm{B}$, and $\mathrm{C}$, a set of ${ }^{14} \mathrm{C}$ data was obtained for ensembles belonging to each group. The $17{ }^{14} \mathrm{C}$ ages with a standard deviation $<100 \mathrm{yr}$ were obtained mainly for the seriated ensembles. One ${ }^{14} \mathrm{C}$ age was obtained for the level $14 \mathrm{G} .3$ of the Grotte du Mourre de la Barque. This occupation level was too poor to be seriated but it provided a big vessel with cordons and lentil-like applications, which is typical for group B. The definitive set consists of 7 ages for group A, 4 for group B, and 6 for group C (Table 2).

Dates were calibrated using OxCal 3.10 (Bronk Ramsey 1995, 2001) and the IntCal04 atmospheric data (Reimer et al. 2004). The distribution of calibrated ages shows a large overlap of the calendar ages between the groups A, B, and C (1- $\sigma$ range): A between 5370 and $5070 \mathrm{cal} \mathrm{BC}$; B: 5330 and $5050 \mathrm{cal} \mathrm{BC}$; C: 5310 and $5030 \mathrm{cal} \mathrm{BC}$ (Figure 4). The calibrated dates sequence of group A followed by $\mathrm{C}$, which would support the sequence of Abri de la Font des Pigeons. The calibrated dates of group B, however, overlap both with those of group A and group C, so that the chronological position of group $\mathrm{B}$ cannot be clarified with ${ }^{14} \mathrm{C}$ dates.

The overlap between the data of groups A-B and B-C could partly be due to taphonomic processes. This is probably the case for the 2 oldest ages from layer D4/16 of the Grotte du Mourre de la Barque (ETH 27979 and ETH 27980). Here, one must accept the possibility of post-depositional sample displacement, since this cave also provides some indications of an earlier occupation that belonged to our group B (layer 14G.3, in a nearby sector of the cave). For the other sites, post-depositional processes cannot explain an overlap between the data of each group because there is no evidence of older or younger occupational layers.

In order to test if the present set of ${ }^{14} \mathrm{C}$ ages supports the proposed sequence of $\mathrm{A}-\mathrm{B}-\mathrm{C}$ groups, the data set was submitted to a Bayesian calibration (Buck et al. 1994) using the program OxCal v 3.10. (Bronk Ramsey 1995, 2001). Our premise was that groups A, B, and C follow each other and that there is no overlap but also no hiatus between them. The results of this analysis (Figure 5) show that 
C
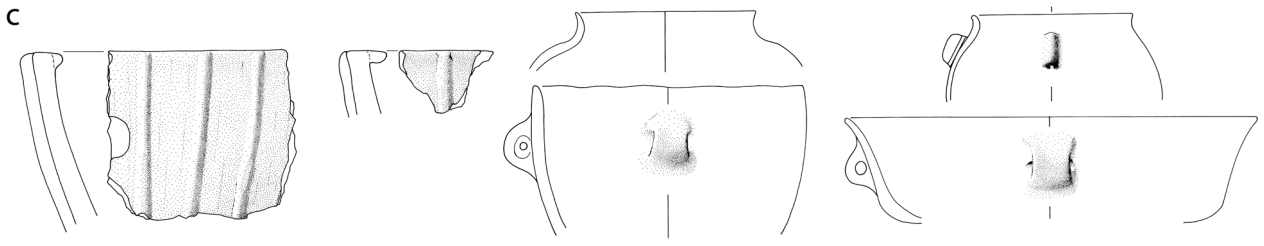

$\mathrm{b}$
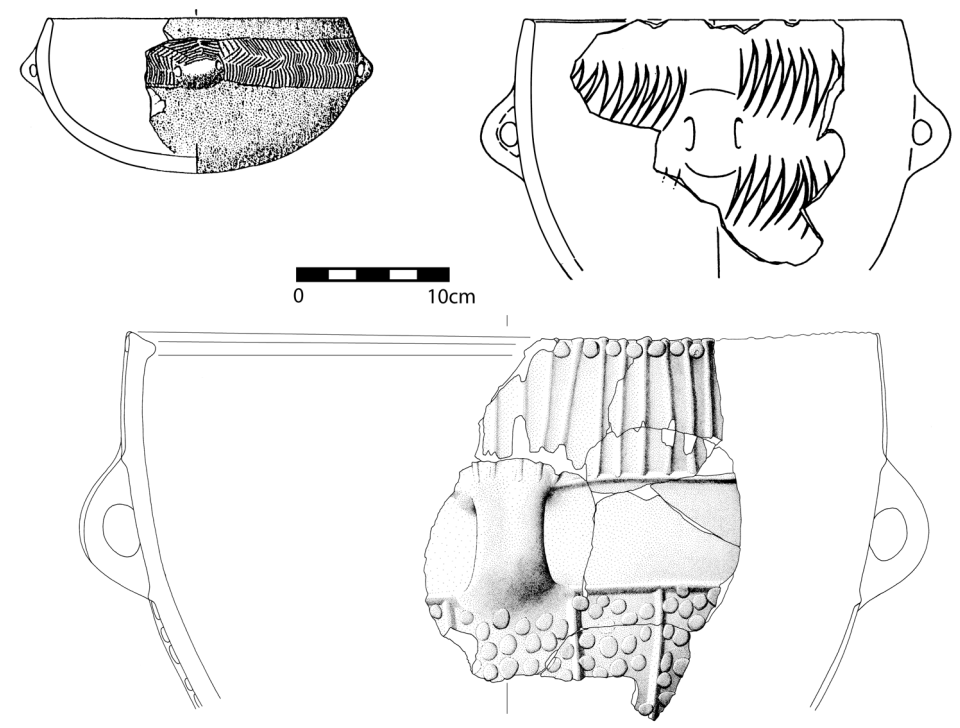

a
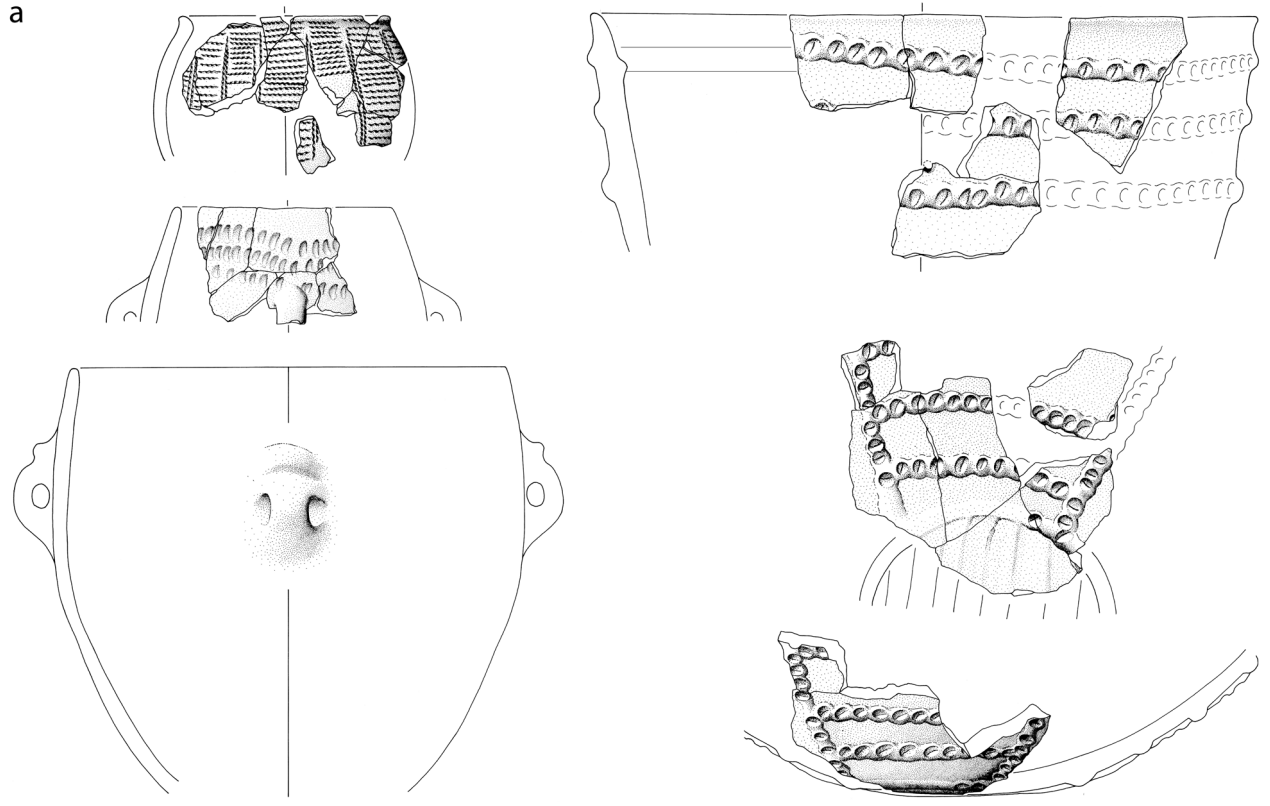

Figure 3 The 3 groups of the Cardial culture in southern France. A: Baume d'Oullins, layer 6 (Roudil and van Willigen 2002); B: Baume Fontbrégoua, layers 47-35 (Echallier and Courtin 1994) and Grotte du Mourre de la Barque, layer 14G.3 (van Willigen 2003); C: Grotte du Mourre de la Barque, layer D4/16 (van Willigen 2003). 
Table 2 List of ${ }^{14} \mathrm{C}$ dates (ETH 27975 has been by mistake published with a value of $6230 \pm 60 \mathrm{BP}$; van Willigen et al., in press).

\begin{tabular}{llllll}
\hline Site & Lab nr & Sample & Date BP & $\delta^{13}$ C (\%o) & Bibliography \\
\hline Baume d'Oullins, & ETH 27972 & bone (Bos sp.) & $6510 \pm 60$ & $-17.4 \pm 1.2$ & unpublished \\
layer 6 & ETH 27973 & bone (large rum.) & $6265 \pm 65$ & $-19.6 \pm 1.2$ & \\
& ETH 27974 & bone (Bos sp.) & $6250 \pm 60$ & $-18.6 \pm 1.2$ & \\
& ETH 27975 & bone (large rum.) & $6360 \pm 60$ & $-18.7 \pm 1.2$ & \\
Le Baratin, structure 5 & LYON 99 & charcoal & $6145 \pm 70$ & $\mathrm{n} / \mathrm{a}$ & Sénépart 1998 \\
Le Baratin, s structure 2 & LYON 100 & charcoal & $6125 \pm 80$ & $\mathrm{n} / \mathrm{a}$ & \\
Le Baratin, structure 1 & LYON 252 & charcoal & $6290 \pm 70$ & $\mathrm{n} / \mathrm{a}$ & \\
Mourre de la Barque, & ETH 26417 & caramel & $6305 \pm 55$ & $-26.2 \pm 1.2$ & unpublished \\
layer C6-14G.3 & ETH 27978 & bone (Bos sp./humerus) & $6165 \pm 65$ & $-19.6 \pm 1.2$ & \\
Mourre de la Barque, & ETH 27979 & bone (Bos t./metapo- & $6225 \pm 60$ & $-20.8 \pm 1.2$ & \\
layer D4-16 & & dium) & & & \\
& ETH 27980 & bone (Bos t./metatanus) & $6285 \pm 65$ & $-19.2 \pm 1.2$ & \\
Céron, pit 1 & ETH 27981 & bone (Bos t./tibia) & $6065 \pm 65$ & $-21.0 \pm 1.2$ & \\
Font des Pigeons, & Gif 9997 & charcoal & $5990 \pm 75$ & $\mathrm{n} / \mathrm{a}$ & Buisson-Catil 2001 \\
layer 11/14 & MC 942 & charcoal & $6050 \pm 100$ & $\mathrm{n} / \mathrm{a}$ & Courtin et al. 1985 \\
Les Petites Bâties & Beta 103862 & charcoal & $6290 \pm 50$ & $\mathrm{n} / \mathrm{a}$ & Binder et al. 2002 \\
& Beta 103867 & charcoal & $6230 \pm 50$ & $\mathrm{n} / \mathrm{a}$ & \\
\hline
\end{tabular}

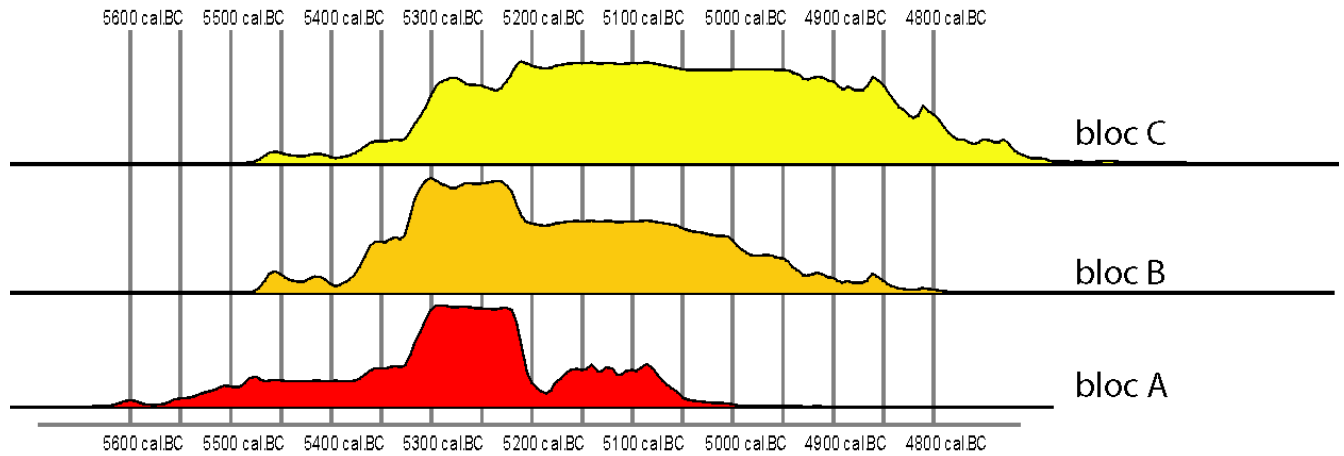

Figure 4 Probability distribution of ${ }^{14} \mathrm{C}$ ages obtained for Groups A, B, and C

the available data do not contradict our hypothesis. Based on the Phase analysis, the shift from Cardial A to Cardial B, which takes place around $5250 \mathrm{cal} \mathrm{BC}$, is followed $100 \mathrm{yr}$ later (i.e. at $5150 \mathrm{cal}$ $\mathrm{BC}$ ) by the transition from Cardial B to Cardial C.

\section{CONCLUSIONS}

We have attempted to develop a chronology for the Cardial culture on the basis of ${ }^{14} \mathrm{C}$ dates from a reconstructed sequence of ensembles considered to be homogenous. This procedure has proved to be a good alternative to the examination of stratigraphies from caves, which is common in southwestern Europe. Usually, these stratigraphies provide neither reliable dates nor complete sequences (van Willigen et al., in press). However, our procedure requires the inclusion of further ensembles (if possible, closed finds), which are dated absolutely. Producing a detailed sequence using seriation and correspondence analysis in combination with a sufficient number of ${ }^{14} \mathrm{C}$ dates would enable us 


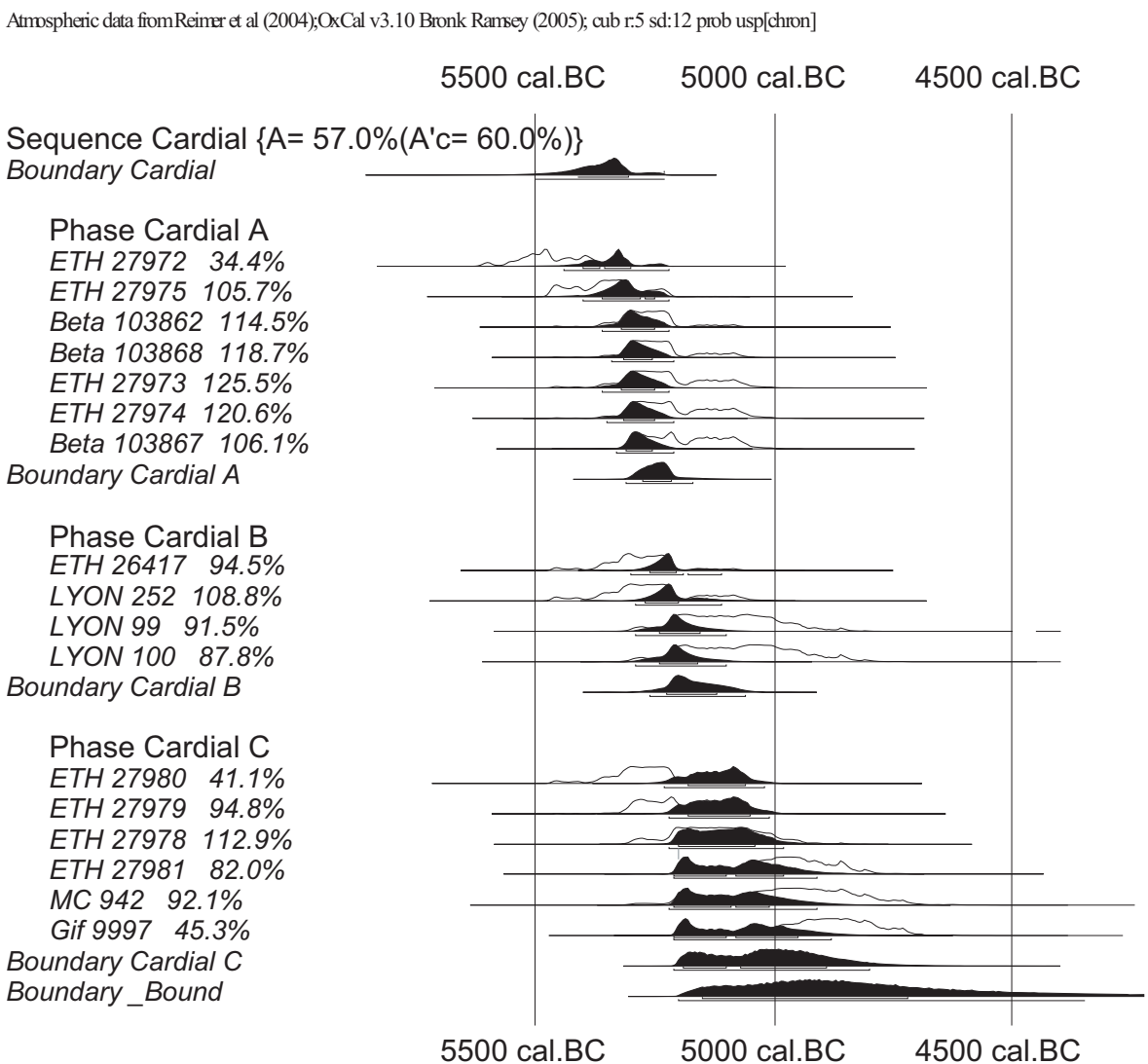

Figure 5 Results of Bayesian Phase model applied to Groups A, B, and C

to apply methods such as wiggle-matching and, thus, to overcome the plateaus in the calibration curve between 5500 and 4800 cal BC.

\section{REFERENCES}

Beeching A. 1987. Les gisements de la baume de Ronze et de Rochas: contribution à l'étude d'un groupe cardial Cèze-Ardèche et de ses prolongements septentrionaux. In: Guilaine J, Courtin J, Roudil JL, Vernet JL, editors. Premières communautés paysannes en Méditerranée occidentale. Actes du Colloque International du CNRS, Montpellier 1983. Paris: CNRS. p 513-22.

Beeching A. 1999. Les premières étapes de circulation et de peuplement dans les Alpes françaises au Néolithique-Apport de la céramique. In: Beeching A, editor. Circulation et identités culturelles alpines à la fin de la préhistoire-Matériaux pour une étude. Programme CIRCALP 1997-1998. p 427-79.

Bernabeu J, Molina Ll, Esquembre MA, Ramón J, de Dios Boronat J. In press. La ceramica impresa mediterranea en el origen del Neolitico de la peninsula Ibérica. In: Hommage à J. Guilaine.

Binder D. 1991. Une économie de chasse au Néolithique ancien-la grotte Lombard à Saint-Vallierde-Thiey (Alpes-Maritimes). Paris: éd. du CNRS.

Binder D, Jallot L, Thiébault S. 2002. Les occupations néolithiques des Petites Bâties (Lamotte-du-Rhône, Vaucluse). Archéologie du TGV Méditerranée, Fiches de synthèse. Tome 1, la Préhistoire. Lattes: CNRS. p 103-22.

Bronk Ramsey C. 1995. Radiocarbon calibration and analysis of stratigraphy: the OxCal program. Radiocarbon 37(2):425-30.

Bronk Ramsey C. 2001. Development of the radiocarbon calibration program. Radiocarbon 43(2A):355-63.

Buck CE, Litton CD, Scott EM. 1994. Making the most of radiocarbon dating: some statistical considerations. Antiquity 68(259):252-63.

Buisson-Catil J. 2001. Un gisement de plein air du Néolithique ancien à Céron (Vénasque, Vaucluse). Bulletin du Groupe Archéologique de Carpentras et 
de sa Région 12:40-5.

Courtin J 1967. La grotte de l'Eglise à Baudinard (Var). Gallia Préhistoire 10:282-99.

Courtin J. 1974. Le Néolithique de la Provence. Paris: Klincksieck.

Courtin J, Evin J, Thommeret Y. 1985. Révision de la stratigraphie et de la chronologie absolue du site de Châteauneuf-lès-Martigues (Bouches-du-Rhône). L'Anthropologie 89:543-56.

Courtin J, Binder D. 1986. Les styles céramiques du Néolithique ancien provençal. Nouvelles migraines taxinomiques? In: Demoule JP, Guilaine J, editors. Le Néolithique de la France. Hommage à Gérard Bailloud. Paris: Picard.

Dangel L. 1997. Contribution à l'étude de la céramique du Néolithique ancien et du Néolithique moyen: l'abri de la Font des Pigeons, Châteauneuf-lès-Martigues. Mémoire de Maîtrise de l'Université de Provence.

Echallier J-C, Courtin J. 1994. Approche minéralogique de la poterie du Néolithique de la Baume Fontbrégoua à Salerne (Var). Gallia Préhistoire 36:267-97.

Escalon de Fonton M. 1974. From the end of the Ice Age to the first agriculturists. In: Piggott S, Daniel G, McBurney C, editors. France Before the Romans. Park Ridge, NJ, USA: Noyes. p 61-101.

Guilaine J, Manen C, Vigne JD. 2007. Pont de RoqueHaute, Nouveaux regards sur la Néolithisation de la France méditerranéenne. Toulouse.

Hameau P, Acovitsioti-Hameau A, Helmer D, PahinPeytavy AC, Vigarie H, Desse-Berset N. 1994. La Baume Saint-Michel-Mazaugues (Var). Bulletin Archéologique de Provence 23:3-40.

Montjardin R. 1966. Le gisement néolithique d'Escanin aux Baux-de-Provence (Bouches-du-Rhône). Cahiers Rhodaniens 13:5-88.

Montjardin R. 1969-1970. Le gisement néolithique d'Escanin aux Baux-de-Provence (Bouches-du-
Rhône). Cahiers Rhodaniens 15:5-152.

Paccard M. 1957. L'abri de l'Eglise (Méthamis, Vaucluse). Bulletin du Musée d'Anthropologie Préhistorique de Monaco 4:189-207.

Reimer PJ, Baillie MGL, Bard E, Bayliss A, Beck JW, Bertrand CJH, Blackwell PG, Buck CE, Burr GS, Cutler KB, Damon PE, Edwards RL, Fairbanks RG, Friedrich M, Guilderson TP, Hogg AG, Hughen KA, Kromer B, McCormac G, Manning S, Bronk Ramsey C, Reimer RW, Remmele S, Southon JR, Stuiver M, Talamo S, Taylor FW, van der Plicht J, Weyhenmeyer CE. 2004. IntCal04 terrestrial radiocarbon age calibration, 0-26 cal kyr BP. Radiocarbon 46(3):1029-58.

Roudil JL, van Willigen S. 2002. La céramique du Néolithique ancien de la Baume d'Oullins (Le Garn, Gard). Ardèche Archéologie 19:1-26.

Roudil JL, Roudil O, Soulier M. 1979. La grotte de l'Aigle à Méjannes-le-Clap (Gard) et le Néolithique ancien du Languedoc oriental. Montpellier: Société Languedocienne de Préhistoire.

Sénépart I. 1998. Données récentes sur le site cardial du Baratin (Courthézon, Vaucluse). In: D'Anna A, Binder D, editors. Production et identité culturelleActualité de la recherche. Rencontres Méridionales de Préhistoire Récente. Actes de la $2^{\text {ème }}$ session, Arles 1996. Antibes: ADPCA. p 427-34.

van Willigen S. 2003. Les occupations néolithiques du Mourre de la Barque - campagne 2003. Document final de Synthèse, SRA et UMR 6636, Aix-enProvence.

van Willigen S. 2006. Die Neolithisierung im nordwestlichen Mittelmeerraum. Iberia Archaeologica 7, Mainz: $\mathrm{Ph}$. von Zabern.

van Willigen S, Hajdas I, Bonani G. In press. La chronologie du groupe Bas-Rhône-Provence du Cardial franco-ibérique. In: Colloque sur le Néolithique ancien méditerranéen, Toulouse 2007. 